\title{
Comparative Analysis of Traditional versus Authentic Teaching Method in DNA Extraction to Biology Students
}

\author{
Vanessa Joy P. Gasat ${ }^{1,2}$, Michael Prince N. Del Rosario ${ }^{1,3}$, Flormay O. Manalo \\ ${ }^{1}$ No. 2219 CM Recto Ave., University of the East-Graduate School, Manila, Philippines \\ ${ }^{2}$ University of the Cordilleras, Baguio City, Benguet, Philippines \\ ${ }^{3}$ Lorma Colleges, San Fernando, La Union, Philippines
}

\begin{abstract}
DNA is the blueprint of life. Teaching Science, particularly DNA, is included in every Table of specifications mandated by the curriculum. Traditional method in teaching includes the use of lecture and utilizes pen and paper as a form of assessment. Authentic method on the other hand makes use of real life experience.

The purpose of this study is to compare the effectivenessof teaching Science using the pen-and-paper strategy and authentic approach. This study uses DNA extraction as the topic. The researchers gathered 10 Biological Science students who were picked randomly from the reviewees of the review center. The first treatment involved using the traditional method in teaching by lecturing and the second treatment involved using the authentic method by showing the actual process of DNA extraction. Every after treatment, similar post tests were given to the respondents. The results are compared and data gathered are as follows: Mean of 5.4 for traditional and 7.6 for authentic. The median for traditional is 6 while 8 for authentic. The mode of the distribution for traditional is 6 and 8 for authentic. The data suggest that the students learned from authentic method of teaching Science better as compared to the use of traditional method. The results will be of help to teacher education institutions and the government in creating curriculum based on what strategy students learn best. The researchers recommend the replication and continuation of this study.
\end{abstract}

Keywords-Traditional Teaching Method (Pen-andPaper), Authentic Teaching Method (Real-Life).

\section{INTRODUCTION}

DNA, or deoxyribonucleic acid, is the hereditary material in humans and almost all other organisms. Nearly every cell in a person's body has the same DNA. Most DNA is located in the cell nucleus (where it is called nuclear DNA), but a small amount of DNA can also be found in the mitochondria (where it is called mitochondrial DNA or mtDNA). ${ }^{[1]}$

DNA (DeoxyriboNucleic Acid) is a long stringy molecule that can be extracted from any biological material such as living or conserved tissues, cells and virus particles. A number of basic procedures are carried out to isolate and purify DNA. First the cell is broken open to expose its DNA. This is achieved by blending or grinding the cell. The next step involves breaking down and emulsifying the fat and proteins that make up the cell's membrane. This is achieved by the addition of both salt and detergent solutions. Following this, the DNA is separated from the liquid solution by the addition of an alcohol and centrifugation. This provides the purified DNA ready for use in different applications. ${ }^{[2]}$

Traditional teaching methods are described as being teacher-oriented, in a lecture style and are inflexible. Lessons are usually taught by the teacher introducing skills using a blackboard accompanied by a verbal explanation or lecture. ${ }^{[3]}$

In education, the term authentic learning refers to a wide variety of educational and instructional techniques focused on connecting what students are taught in school to realworld issues, problems, and applications. The basic idea is that students are more likely to be interested in what they are learning, more motivated to learn new concepts and skills, and better prepared to succeed in college, careers, and adulthood if what they are learning mirrors real-life contexts, equips them with practical and useful skills, and addresses topics that are relevant and applicable to their lives outside of school. ${ }^{[4]}$

\section{MATERIALS AND METHODS}

The researchers used lecture method and laboratory method. 10 Biological Science students from Dr. Carl E. Balita Review Center were chosen using the fishbowl method. The 
study was done on March 7, 2017. First, the researchers conducted a 20 minute-formal lecture on DNA extraction of Actinidiadeliciosa (Kiwi fruit). They used the chalk-talk approach and gave post-test afterwards. The students were then regathered and another lecture was conducted. This time they used materials and demonstrated the actual DNA extraction method in Kiwi fruits. Same post test (Appendix A) were given to the students right after teaching using the lecture method and the laboratory method. Measures of central tendencies and variability were used to interpret data. Results were then compared.

\section{Materials used for DNA extraction:}

Kiwi fruit

$70 \%$ rubbing alcohol

Zip lock bag

1 cup dishwashing liquid soap

Salt

Medium-sized Mixing bowl

Measuring spoons and measuring cups

Beaker

Strainer

Funnel

Stirring rod

\section{Procedure for DNA extraction:}

1. Mix $30 \mathrm{~mL}$ of water, $1 / 2$ teaspoon salt and one (1) tablespoon of dishwashing liquid soap in a bowl.

2. Place rubbing alcohol in the freezer to chill.

3. Put the kiwi fruit with stem removed inside a zip lock bag.

4. Place eight (8) tablespoon of salt-soap-water solution into the zip lock bag with the kiwi fruit.

5. Seal the zip lock bag and press out all the air.

6. Mush the kiwi fruit for about 2 minutes until they are fine foamy paste.

7. Strain the kiwi pulp into the beaker.

8. Use a spoon to push it through.

9. Remove the alcohol from the freezer and take $1 / 2$ cup of the chilled rubbing alcohol.

10. Gently pour the alcohol into the kiwi mixture. (Create a fine layer of alcohol on top of the kiwi mixture)

11. Use the stirring rod to remove the cloudy precipitate, which is the DNA from the beaker.

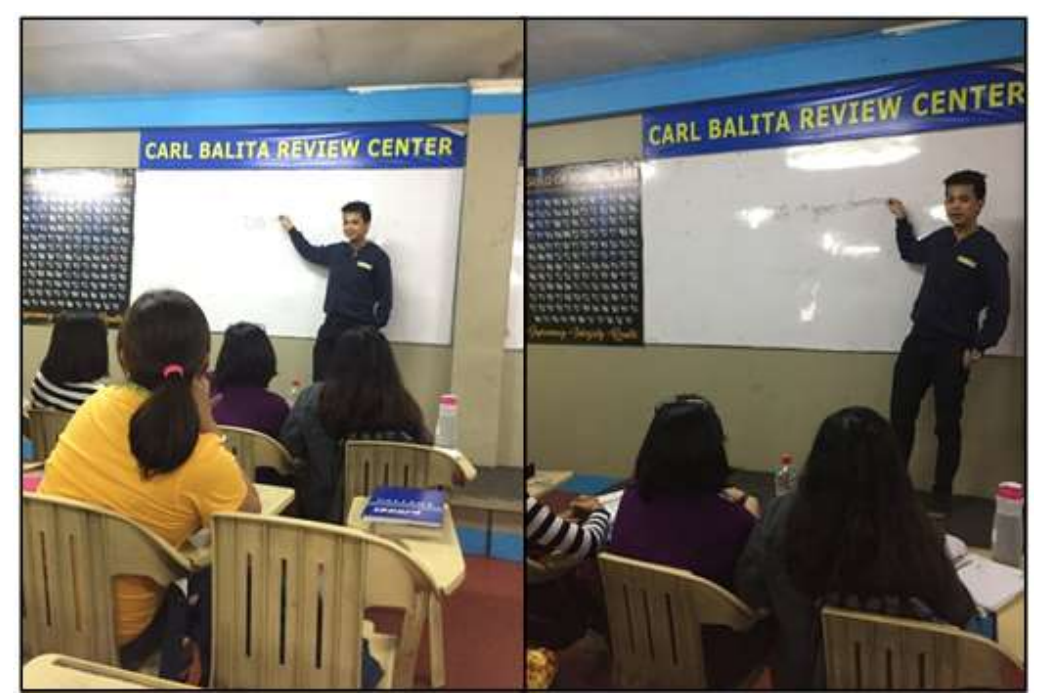

Fig.1: Lecture on teaching DNA extraction of Kiwi fruit (Traditional method) 


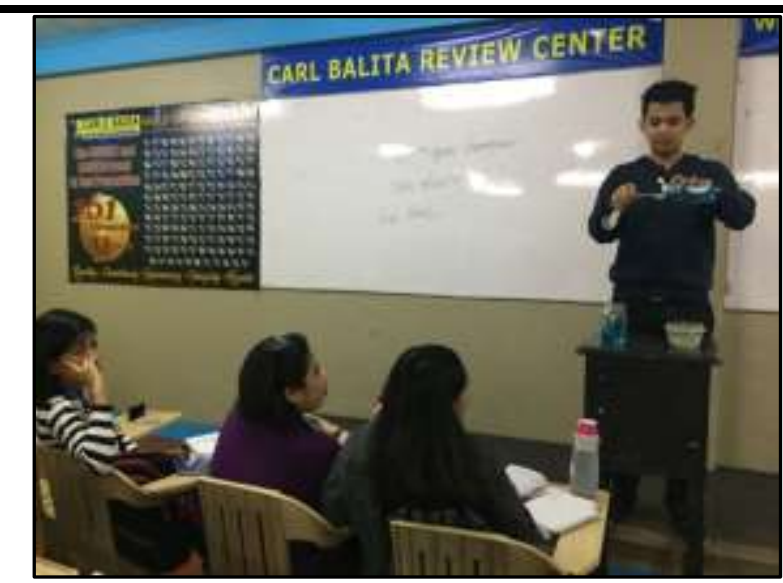

Fig.2: Creating salt-dishwashing soap solution (Authentic approach)

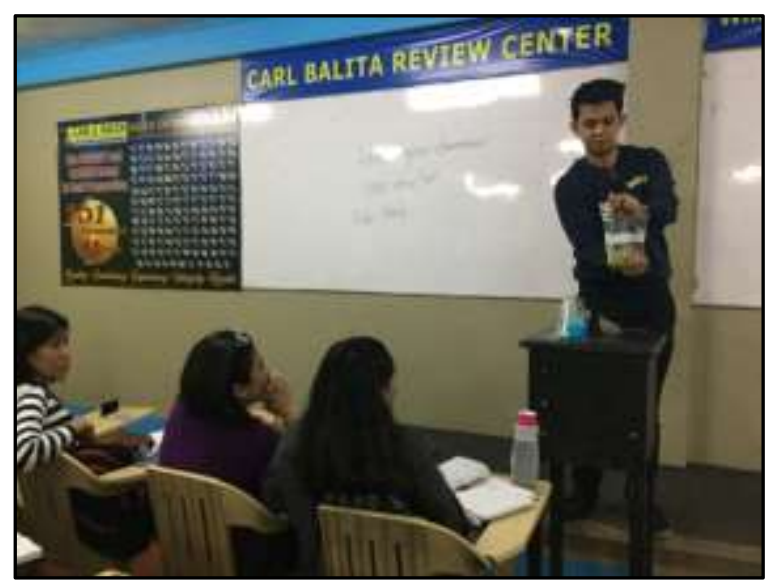

Fig.3: Mushing the kiwi fruit (Authentic approach)

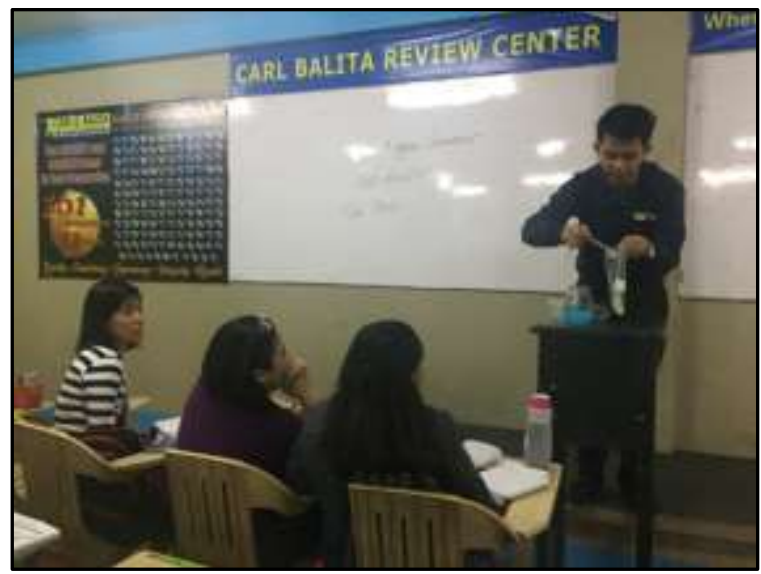

Fig.4: Adding the salt-dishwashing solution to the mushed Kiwi fruit (Authentic approach)

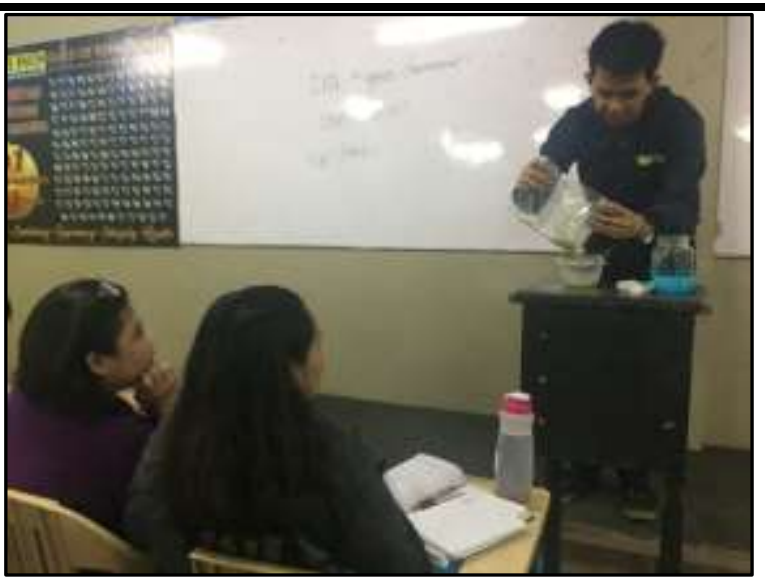

Fig.5: Straining the mixture (Authentic approach)

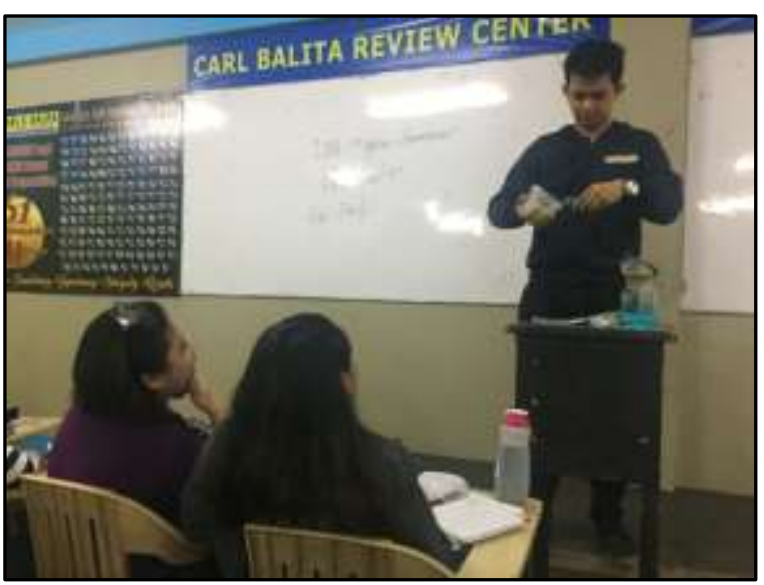

Fig.6: Adding cooled alcohol to the mixture (Authentic approach)

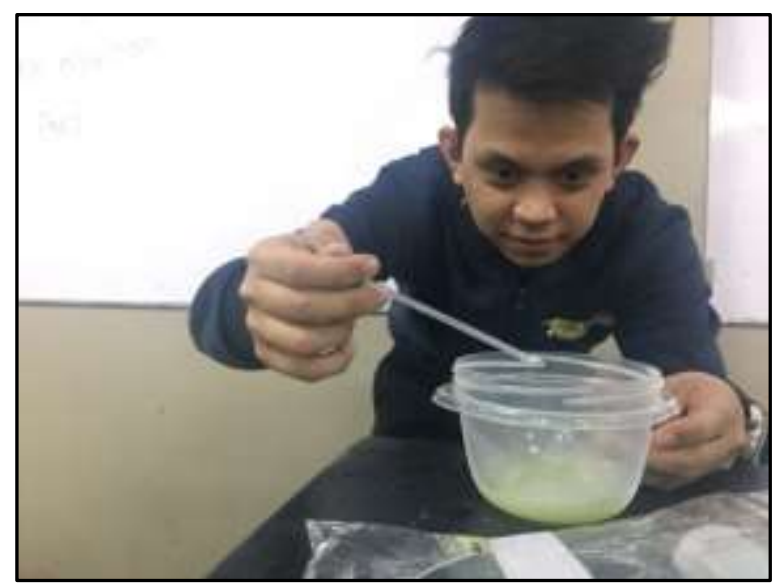

Fig.7: Extracting the DNA from the mixture (Authentic approach) 


\section{RESULTS AND DISCUSSION}

Table.1: The Comparative results of scores of the students using the traditional and authentic method

\begin{tabular}{|l|c|c|}
\hline & Traditional & Authentic \\
\hline Student A & 6 & 8 \\
\hline Student B & 7 & 9 \\
\hline Student C & 2 & 7 \\
\hline Student D & 5 & 5 \\
\hline Student E & 7 & 7 \\
\hline Student F & 8 & 8 \\
\hline Student G & 8 & 8 \\
\hline Student H & 5 & 7 \\
\hline Student I & 6 & 8 \\
\hline Student J & 4 & 9 \\
\hline
\end{tabular}

Table 1 showsthat Student A got a score of $6 / 10$ and $8 / 10$ for traditional and authentic method respectively. Student B got $7 / 10$ and $9 / 10$, Student $C$ got $2 / 10$ and $7 / 10$, Student $D$ got $5 / 10$ and $5 / 10$, Student $E$ got $7 / 10$ and $7 / 10$, Student $F$ and $\mathrm{G}$ both got $8 / 10$ and $8 / 10$, Student $H$ got $5 / 10$ and $7 / 10$, Student I got $6 / 10$ and $8 / 10$, Student $J$ got a score of $4 / 10$ and $9 / 10$ for traditional and authentic method. The table shows that students A, B, C, H, I and J had better scores from the authentic method as compared to the traditional method. However, students $\mathrm{E}, \mathrm{F}$ and $\mathrm{G}$ showed no difference in their scores using any methods.

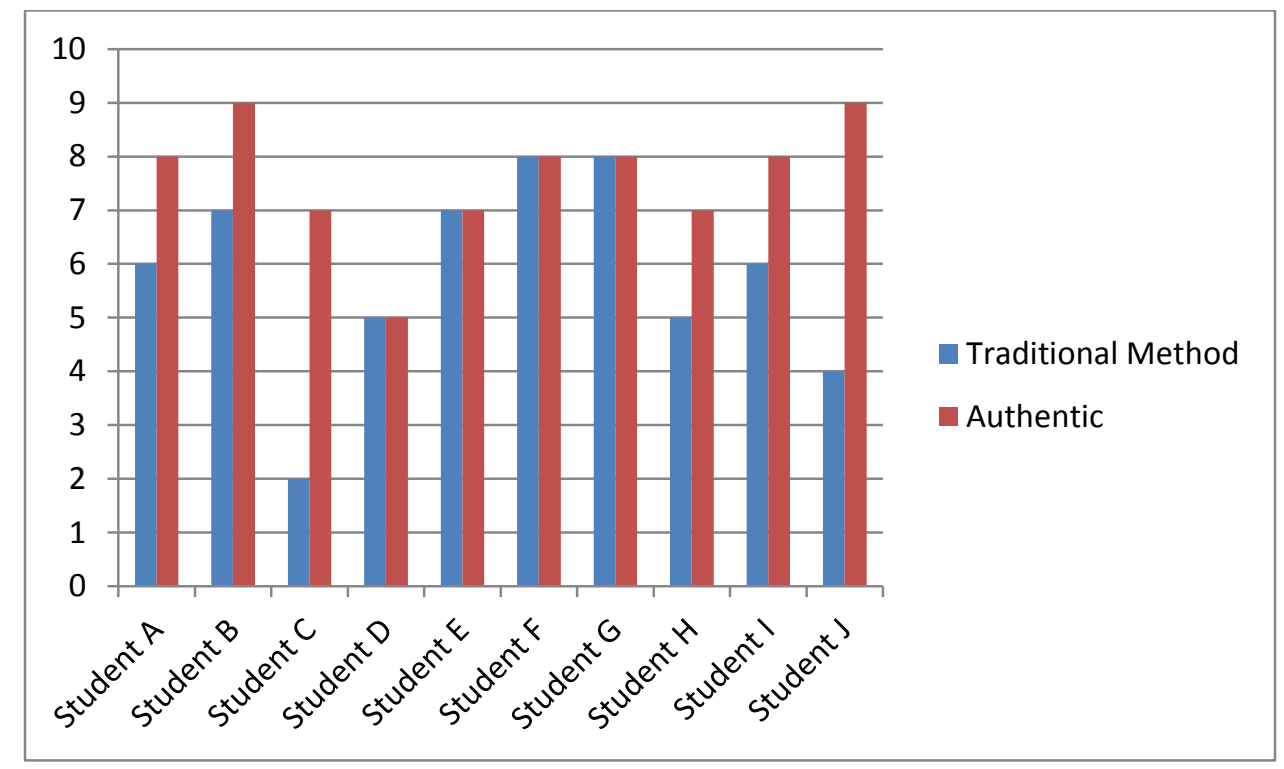

Fig.8: Comparative results of scores of the students using the traditional and authentic method

Figure 8 represents the post test scores of the students in both traditional and authentic method. The highest score for traditional method is $8 / 10$ and the lowest score is $2 / 10$ while for the authentic method, the highest score is $9 / 10$ and the lowest score is $5 / 10$.

Table.2: Statistical Analysis of the students score in Traditional and Authentic teaching

\begin{tabular}{|l|r|r|l|r|r|}
\hline & Traditional & Authentic & & Traditional & Authentic \\
\hline Mean & 5.4 & 7.6 & $\begin{array}{l}\text { Standard } \\
\text { Deviation }\end{array}$ & 1.57 & 1.17 \\
\hline Median & 6 & 8 & Variance & 2.27 & 1.38 \\
\hline Mode & 6 & 8 & & & \\
\hline
\end{tabular}

Table 2 shows that the mean score for the traditional method is 5.4 while 7.6 for the authentic method. The median of the traditional method is 6 while 8 for the authentic method. The mode for traditional method is 6 while 8 for authentic method. The standard deviations for traditional and authentic method are 1.57 and 1.17 respectively. The variance for traditional method is 2.27 while 1.38 for authentic method. 


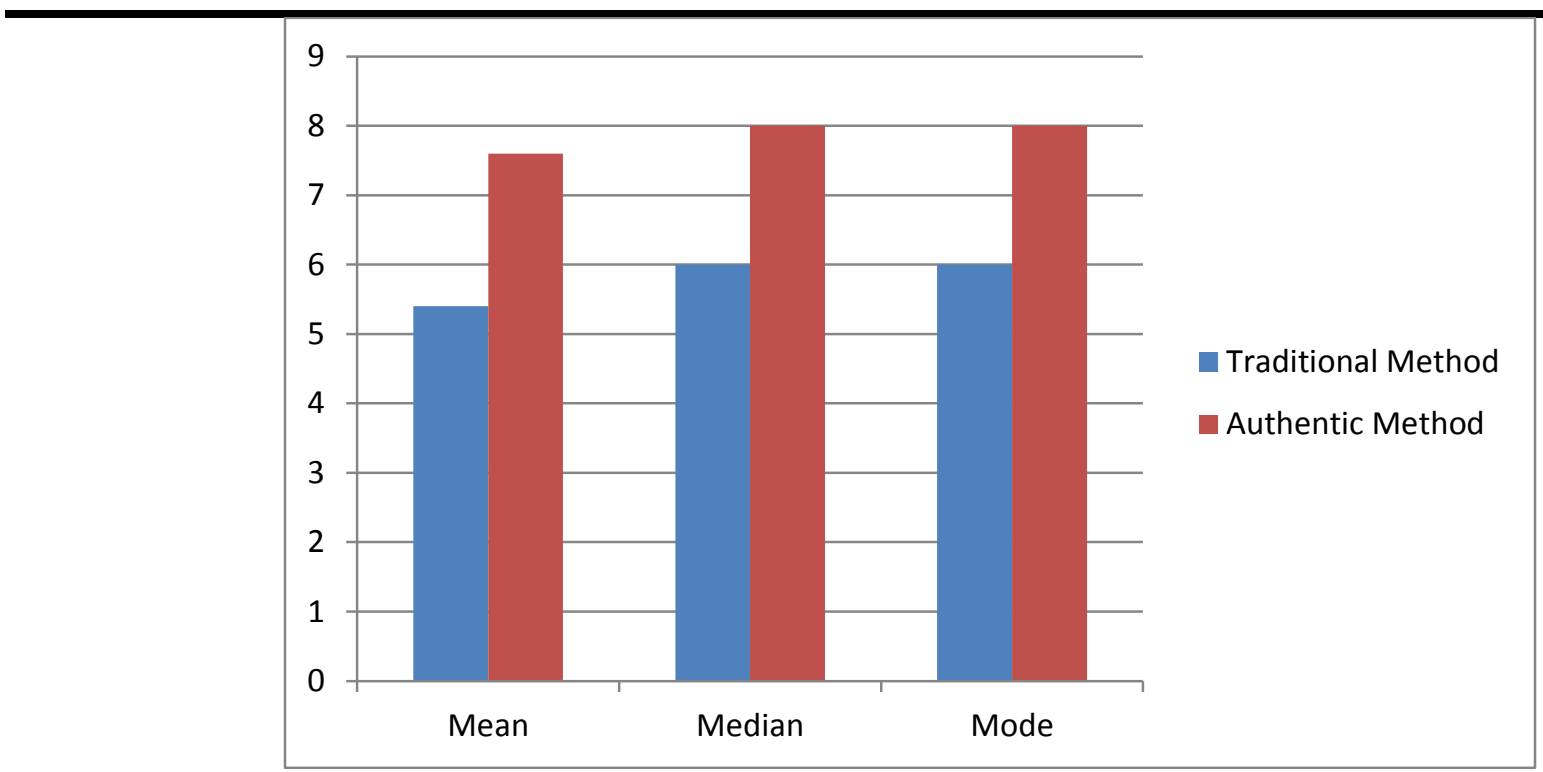

Fig.9: Central tendency of students score in traditional and authentic teaching

Figure 9 shows the result of the score distribution of the students. For traditional method, the mean is 5.4, median 6 and mode of 6. For the authentic method, the mean score is 7.6, median 8 and mode of 8 . From these scores, it can be inferred that students scored higher using the authentic method compared with the traditional method.

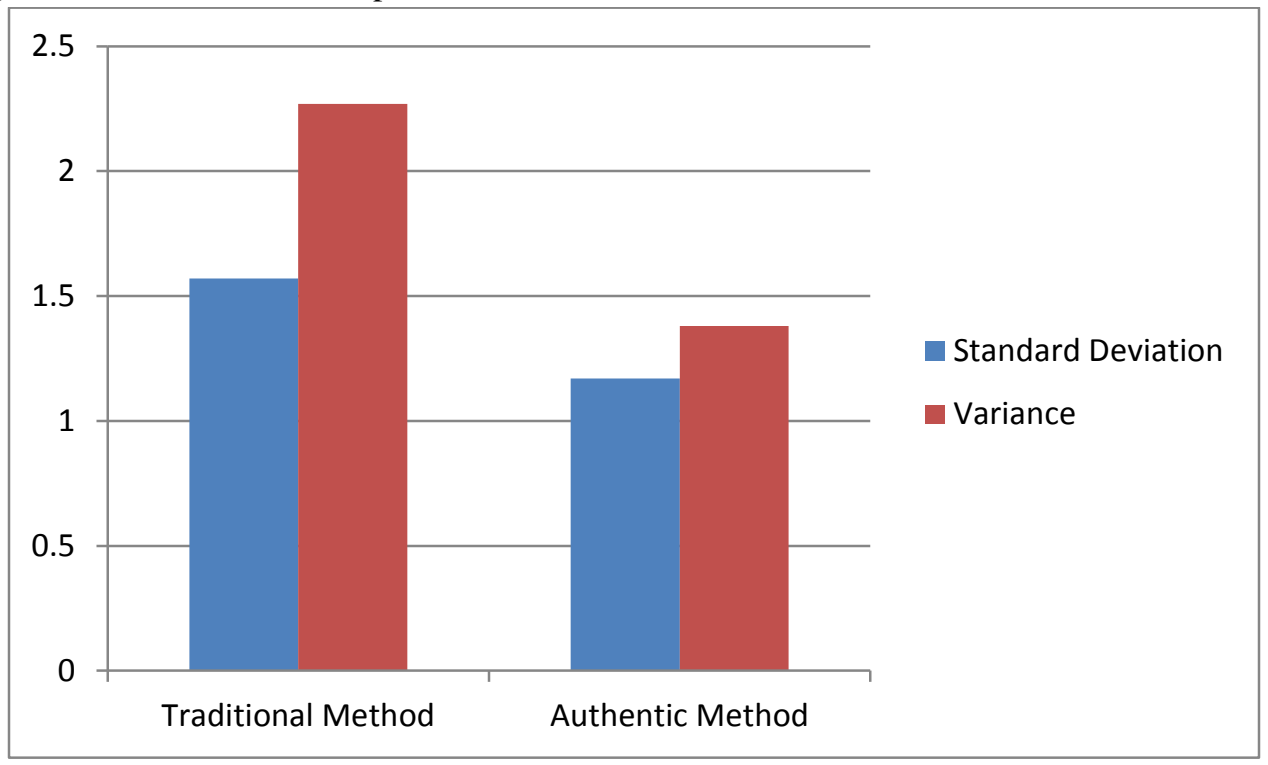

Fig.9: Variation of students score in traditional and authentic teaching

Figure 9 shows the variability of the students' scores. In traditional method, the standard deviation is 1.57 and the variance is 2.27 . In the authentic method, the standard deviation is 1.17 and the variance is 1.38. Since the standard deviation of the authentic method is lower compared with the traditional method, it implies that students' scores are more homogenous, more concentrated and less farther from the mean. This suggests better learning since there is lesser variability.

\section{CONCLUSION AND RECOMMENDATION}

After conducting both traditional and authentic methods of teaching DNA extraction to Biological Science students, the following are inferred: Mean of 5.4 for traditional and 7.6 for authentic. The median for traditional is 6 while 8 for authentic. The mode of the distribution for traditional is 6 and 8 for authentic. For traditional assessment the standard deviation is 1.57 and the variance is 2.27 while for authentic the standard deviation is 1.17 and the standard deviation is 1.38 . 
The data suggest that the students learned from authentic method of teaching Science better as compared to the use of traditional method. Students got higher scores using the authentic method of teaching DNA extraction.

The researchers recommend the utilization of authentic method of teaching not just in Science but in all subject areas as applicable to the students and topic. They also recommend a review of the existing curriculum in the Philippines that focuses more on the traditional methods of giving instructions.

The results will be of help to teacher education institutions and the government in creating curriculum based on what strategy students learn best. The researchers strongly recommend the replication and continuation of this study and to use larger sample size for more accurate results.

\section{ACKNOWLEDGEMENT}

The researchers of this study would like to extend their gratitude to the students of Dr. Carl E. Balita Review who participated in the said study and to the center who allowed the commencement of the research. Also, the researchers would like to thank Dr. Alma Nacua and Dr. Lourdes Terrado for their unending support in conducting the research.

\section{REFERENCES}

[1] What is DNA. (2017, March 07). Retrieved from https://ghr.nlm.nih.gov/primer/basics/dna

[2] DNA Extraction. (n.d.). Retrieved from http://www.whatisbiotechnology.org/science/extraction

[3] "What are some examples of traditional methods." (n.d.).Retrieved from https://www.reference.com/education/examplestraditional-teaching-methods-a227abf51002c6f0

[4] Hidden curriculum (2014, August 26). In S. Abbott (Ed.), The glossary of education reform. Retrieved from http://edglossary.org/hidden-curriculum

\section{APPENDIX A POST TEST QUESTIONNNAIRE ON DNA EXTRACTION}

1. Why do we need to crush the kiwi fruit?
a. It chemically breaks the cell walls apart
b. It will break the cell walls physically
c. It will break the DNA
d. It will promote lysis

2. What should we use to disrupt the cell and the nuclear membrane of each cell to release the DNA?
a. Salt
c. Sugar
b. Dishwashing liquid
d. Ice

3. What is the effect of the salt in our experiment?

a. The salt will neutralize the negative charges on the deoxyribonucleic acid

b. It will dissolve lipids and protein

c. It will increase the acidity of the medium

d. The salt will break the nuclear membrane of the cell

4. The purpose of cooling the mixture is?

a. To slow down degradation process

b. To speed up degradation process

c. To freeze the DNA

d. To neutralize the acid in the DNA

5. What will not be dissolved by using cold alcohol?
a. DNA
c. Cell
membrane
b. Lipids
d. Cell wall

6. What is the effect of using room temperature alcohol?
a. Lesser DNA precipitation
b. Better DNA precipitation
c. No effect on DNA precipitation
d. None of the choices

7. Why is the importance of DNA extraction
a. Identification of people
b. To check for genetic defects
c. To determine parentage of organisms
d. All of the above

8. How many chromosomes are present in a Kiwi fruit?
a. Hexaploid
c. Tetraploid
b. Octoploid
d. Diploid

9. Which is not included in the DNA extraction process?
a. Warming of alcohol
b. Dissolving salt and water
c. Crushing of the kiwi fruits
d. Mixing dishwashing liquid and salt solution

10. What is scientific name of kiwi fruit?
a. Actinidiadeliciosa
b. Fragariaananassa
c. Oryza sativa
d. Malusdomestica 